Systematic Review

\title{
Effects of Systemic Magnesium on Post- operative Analgesia: Is the Current Evidence Strong Enough?
}

Bao-Lin Guo, MD ${ }^{1,2}$, Yan Lin, MD, PhD ${ }^{1,2}$, Wei Hu, MD, PhD³, Chen-Xi Zhen, MD, PhD², Zhao Bao-Cheng, MD, PhD ${ }^{4}$, Huang-Hui Wu, MD, PhD ${ }^{2,5}$, Alan David Kaye, MD, $\mathrm{PhD}^{6}$, Jian-Hong Duan, $\mathrm{MD}, \mathrm{PhD}^{3}$, and Yan $\mathrm{Qu}, \mathrm{MD}, \mathrm{PhD}^{1}$

\footnotetext{
From: ${ }^{1}$ Department of Neurosurgery, Tang'du Hospital, Fourth Military Medical University, Xi'an 71032, China; 2Department of Neurobiology and Collaborative Innovation Center for Brain Science, Fourth Military Medical University,

Xi'an 710032, China; ${ }^{3}$ State Key Laboratory of Military Stomatology, College of Stomatology, Fourth Military Medical University, Xi'an 710032 PR China; ${ }^{4 T h e}$ Healthcare Department of General Political Department Hospital, Beijing, 100120, China; ${ }^{5}$ Department of Anesthesiology, Fuzhou General Hospital Affiliated to Fujian Medical University, Fuzhou 350025, China; ${ }^{6}$ Department of Anesthesiology, Louisiana State University Health Sciences Center, New Orleans, LA

Address Correspondence: Prof. Qu Yan, MD, PhD Department of Neurosurgery, Tang'du Hospital ${ }_{169}$ Changle West Road Xi'an School Fourth Military Medical University, China E-mail: yanquo123@gmail.com

Conflict of interest: Each author certifies that he or she, or a member of his or her immediate family, has no commercial association (i.e., consultancies, stock ownership, equity interest, patent/licensing arrangements, etc.) that might pose a conflict of interest in connection with the submitted manuscript.

Manuscript received: 01-13-2015 Revised manuscript received: 04-02-2015 Accepted for publication: 04-06-2015

Free full manuscript: www.painphysicianjournal.com
}

Background: Clinical studies have been previously carried out on the efficacy of systemic magnesium to minimize postoperative pain, however, with controversial results. A quantitative meta-analysis was performed to evaluate the analgesic efficacy and safety of systemic magnesium on post-operative pain.

Study Design: Comprehensive systematic review of all relevant, publsished randomized controlled trials.

Methods: A search was conducted of published literature in MEDLINE, PsycINFO, Scopus, EMBASE, and the Cochrane Central Register of Controlled Trials (CENTRAL) databases from inception to September 2014. Randomized controlled trials (RCTs) that compared magnesium with placebo were identified. Effects were summarized using standardized mean differences (SMDs), weighed mean differences (WMD), or odds ratio (OR) with suitable effect model.

Results: Twenty-seven RCTs involving 1,504 patients were included. In total, peri-operative magnesium significantly reduced the pain score at rest (SMD, $-1.43,95 \% \mathrm{Cl},-2.74$ to -0.12 , < 0.01 ). Magnesium significantly reduced analgesic consumption (SMD, $-1.72,95 \% \mathrm{Cl},-3.21$ to -0.23 ) in patients undergoing urogenital, orthopaedic, and cardiovascular surgeries, but was inconclusive for patients receiving gastrointestinal surgeries. The obvious analgesia of systemic magnesium was observed on reducing the pain score during movement at 24 hours after operation (SMD, $-0.05,95 \% \mathrm{Cl},-0.43$ to 0.32 ). Moreover, magnesium administration showed a beneficial effect with regard to intra-operative hemodynamics and reduced extubation time in the cardiovascular surgery patients (WMD, $-29.34 \mathrm{~min}, 95 \% \mathrm{Cl},-35.74$ to $-22.94, P<0.01$ ).

Limitations: Focused only on the quality of analgesia on postoperative pain with regards to surgery type.

Conclusions: Our study suggests that systemic magnesium during general anesthesia significantly decreases post-operative pain scores without increasing adverse events. It should be noted that since there are 18 ongoing RCTs without published data, it is still premature to draw conclusions on the long-term analgesic effects of magnesium as well as potential gender or age difference.

Key words: Magnesium, post-operative pain, meta-analysis

Pain Physician 2015; 18:405-417 
$\square$ he treatment of post-operative pain is an important health care issue. Aggressive pain prevention peri-operatively can yield both short- and long-term benefits. Unrelieved or poorly managed acute pain affects patient recovery, ability to go home, return to normal functioning, and the likelihood of developing chronic pain. The implication of magnesium in pain reduction lies in its ability to serve as a noncompetitive NMDA receptor antagonist by preventing extracellular calcium movement into the cell and by attenuating central sensitization. Specifically, the blockade of glutamate and aspartate at the NMDA receptor by magnesium is the central mechanism (1). In addition to the effects of magnesium on NMDA receptors, it blocks calcium channels, resulting in potentially clinically beneficial peripheral vasodilation, bronchodilation, and uterine relaxation via its effects on smooth muscle, and demonstrated post-operative analgesia (1).

Magnesium has been used to improve post-operative analgesia since the first randomized clinical trial (RCT) in 1996 (2). However, the efficacy of magnesium on post-operative pain from RCTs remains controversial (3-5). Peri-operative magnesium does not confer any significant analgesic benefit according to 2 previous reviews $(6,7)$. This conclusion was based on a small number of trials and these previous reviews provided qualitative instead of quantitative data reporting $(6,7)$. In this regard, a recent quantitative meta-analysis suggested a positive relationship between magnesium and post-operative pain (1) independent of the mode of administration (e.g., bolus or continuous infusion).

There are a number of reasons why the beneficial

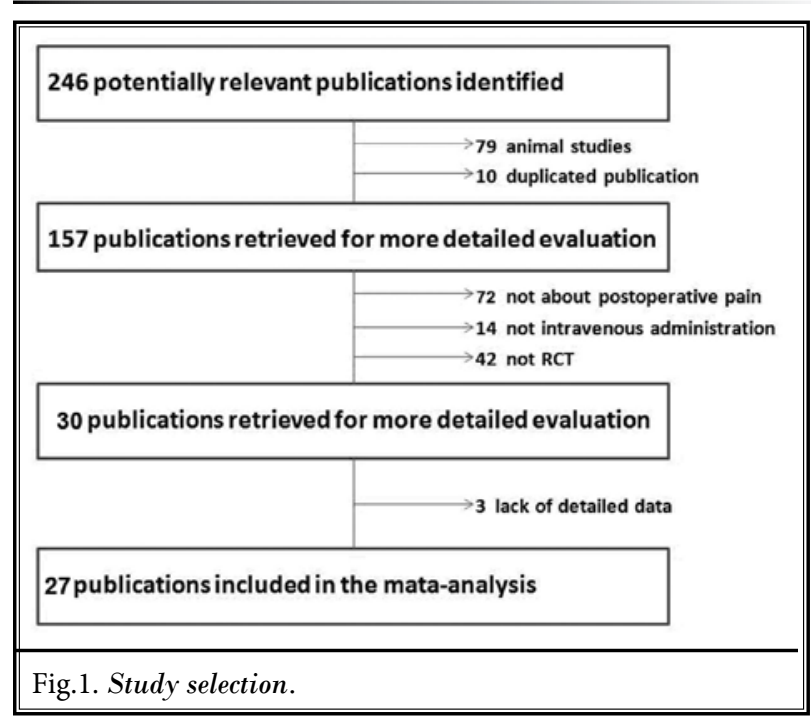

effects of magnesium on post-operative pain remain controversial. First, there were only 2 endpoints at one time point (e.g., pain score and analgesic consumption) in the previous studies, resulting in limited conclusions being reached concerning the temporal efficacy of magnesium as well as its adverse events. Second, several lately conducted meta-analyses were published without recently completed relevant investigations. Third, some of the included articles in previous meta-analysis had low Jadad scores, which weakened the conclusions. When we were performing the current meta-analysis, 2 meta-analyses were published $(8,9)$. However, only 20 RCTs were included in one meta-analysis with 7 RCTs published in 2012 not being included (8). Therefore, data from 247 more patients were not involved in the most recently published meta-analysis. Although $25 \mathrm{RCTs}$ were included in another study, the efficacy of magnesium was investigated only at 24 hours post-operatively with the longer analgesic effect of magnesium not being meta-analyzed (9). Thus, we performed this comprehensive systematic review of all relevant, published RCTs with all available outcome measures, time points, and adverse events, in an attempt to more precisely identify the role of magnesium in mediating or modulating postoperative analgesia.

\section{Methods}

Based on the Quality of Reporting of Meta-analyses (QUORUM) guidelines (10) and the recommendations of the Cochrane Collaboration (11), we performed the current meta-analysis.

\section{Date Sources and Study Selection}

The electronic databases screened were MEDLINE (1966 through September 2014), psycNFO (1966 through September 2014), Scopus (1966 through September 2014), Embase (1966 through September 2014), and the Cochrane Central Register of Controlled Trials (CENTRAL, Issue 9 of 12, September 2014). Searches were limited to human and performed for all languages. Studies were searched by using the following key words: magnesium; surgery OR surgical OR postoperative OR post and operative; randomized OR randomised; and human; and pain OR analgesia OR nociception; and RCT OR controlled clinical trial OR open label trial (OLT) design.

The literature search yielded 27 studies (Fig. 1) and a total of 1,504 patients completed the treatment, with 749 receiving systemic magnesium. The characteristics of these studies were presented in Table 1. The potential bias of these publications was also summarized (Fig. 1). 
Effects of Systemic Magnesium on Post-operative Analgesia

\begin{tabular}{|c|c|c|c|c|c|c|c|c|c|c|c|c|c|c|c|}
\hline & 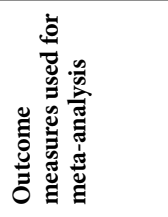 & 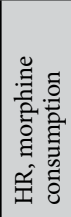 & 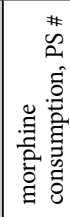 & 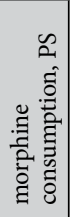 & 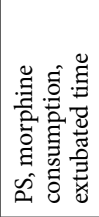 & 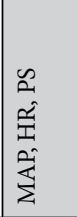 & 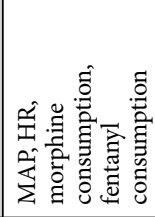 & 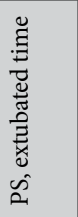 & 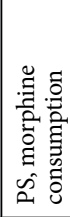 & & 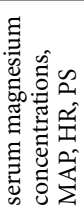 & 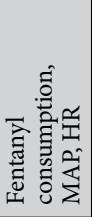 & & 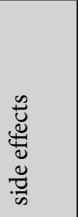 & 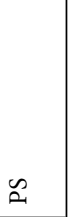 \\
\hline & 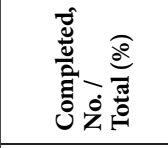 & 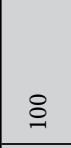 & 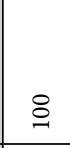 & 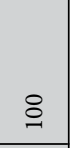 & 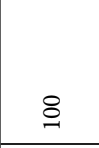 & $\stackrel{-}{-1}$ & 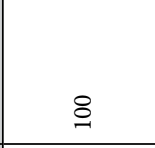 & 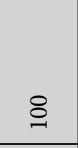 & 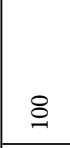 & $\stackrel{-}{-}$ & 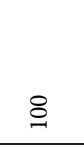 & $\stackrel{-}{\circ}$ & 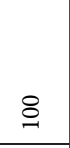 & $\stackrel{-}{\circ}$ & 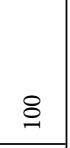 \\
\hline & 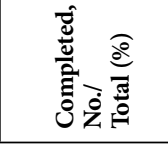 & 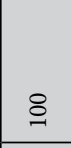 & 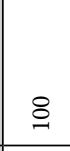 & 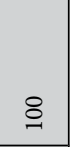 & 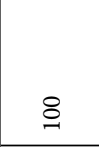 & $\stackrel{-}{\circ}$ & 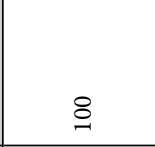 & $\stackrel{9}{\circ}$ & $\stackrel{\circ}{\circ}$ & 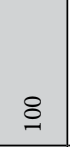 & 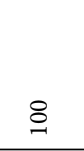 & 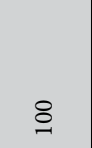 & 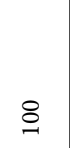 & 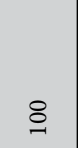 & 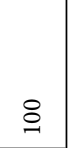 \\
\hline & 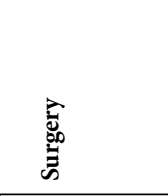 & 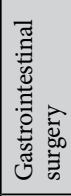 & 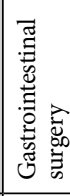 & 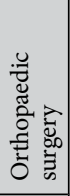 & 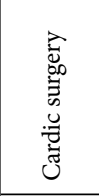 & 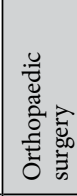 & 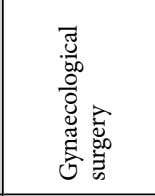 & 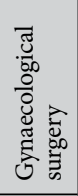 & 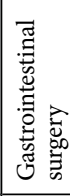 & 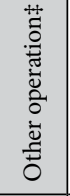 & 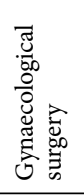 & 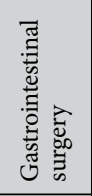 & 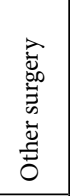 & 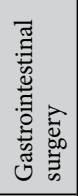 & 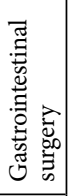 \\
\hline & 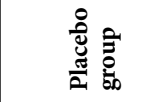 & 竧 & 駡 & 窇 & 竧 & 䔍 & 营 & 营 & 竭 & 竎 & 节 & 蚫 & 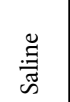 & : & 䔍 \\
\hline & 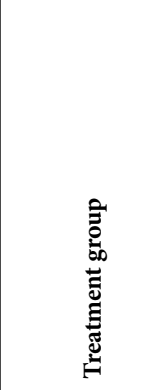 & 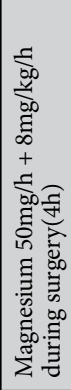 & 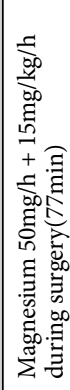 & 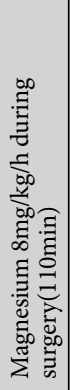 & 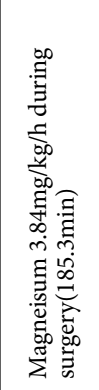 & 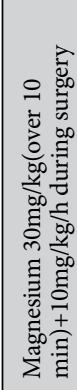 & 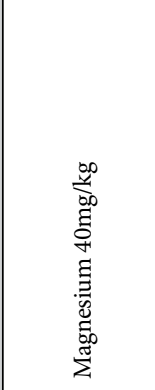 & 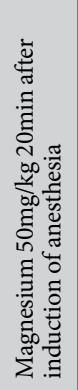 & 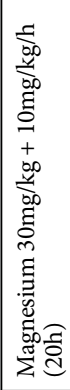 & 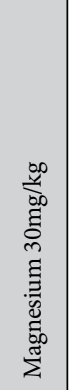 & 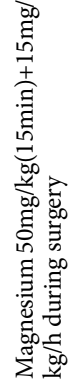 & 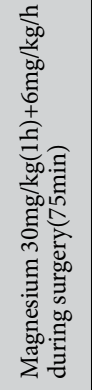 & 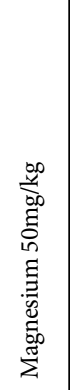 & 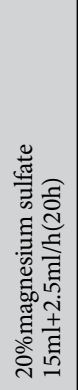 & 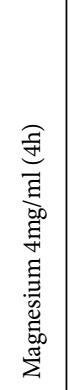 \\
\hline & 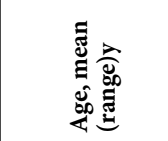 & 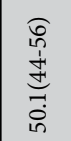 & 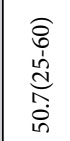 & 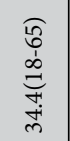 & 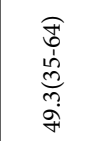 & 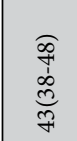 & 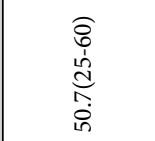 & 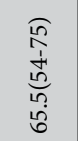 & 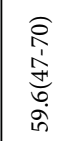 & 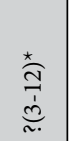 & 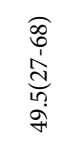 & 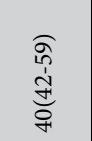 & 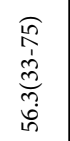 & 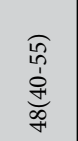 & ๙. \\
\hline & 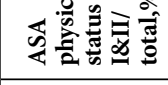 & 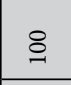 & $\nsubseteq$ & 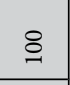 & 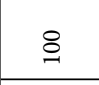 & 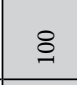 & $\stackrel{一}{ }$ & 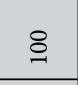 & 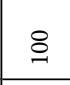 & 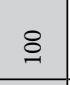 & 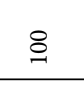 & 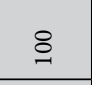 & 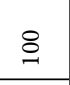 & 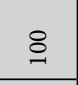 & 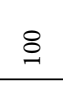 \\
\hline & 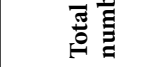 & f & in & 8 & $\stackrel{\infty}{\sim}$ & in & q & m & f & $\infty$ & o & F & in & 7 & 8 \\
\hline & 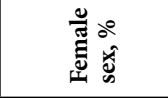 & तn & 苞 & R & in & $f$ & 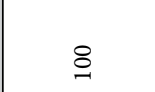 & 0 & $\vec{m}$ & n. & $f$ & ల్లి & f & 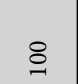 & n. \\
\hline & 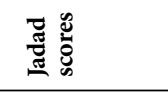 & in & $r$ & in & in & in & 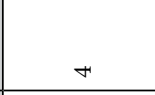 & in & + & in & in & in & in & in & in \\
\hline & 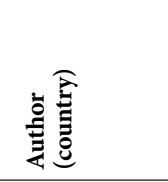 & 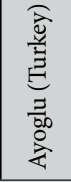 & 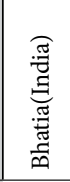 & 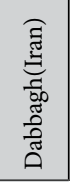 & 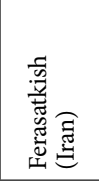 & 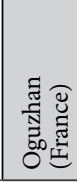 & 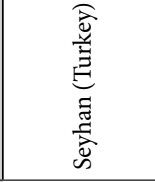 & 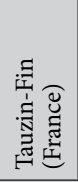 & 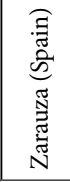 & 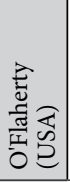 & 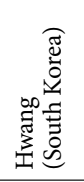 & 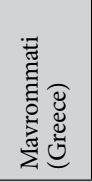 & 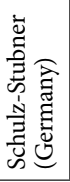 & 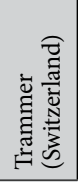 & 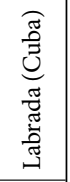 \\
\hline
\end{tabular}

www.painphysicianjournal.com 
Pain Physician: September/October 2015; 18:405-417

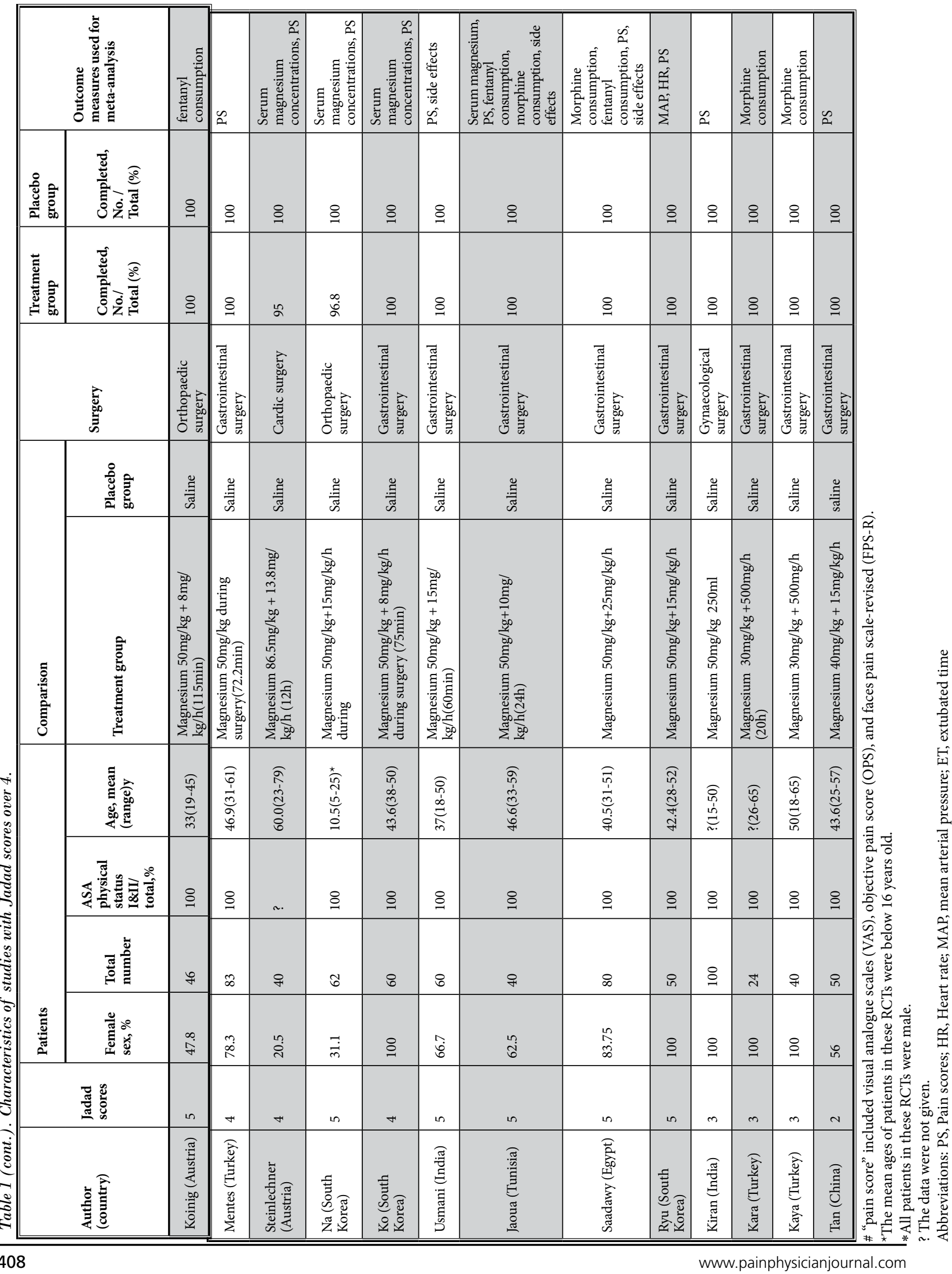




\section{Data Extraction}

Two of the study authors independently screened titles and abstracts of potentially eligible investigations. The full text articles were examined independently by 2 of the study authors to determine whether they met inclusion criteria. Two of the study authors independently extracted information (e.g., study characteristics and results) using data extraction forms. Point estimates for selected variables were extracted and checked by 2 other reviewers. All discrepancies were rechecked and consensus was achieved by discussion.

Based on outcome measurements reported in the RCTs, pain scores, analgesic consumption, and other outcomes which are used to evaluate the safety of systemic magnesium in treating post-operative pain were selected for critical review. Serum magnesium concentration was an additional outcome. When researchers reported more than one scale for the same outcome, the following priority was employed:

1. Pain score: pain intensity measured with visual analogue scales (VAS) or numerical rating scale (NRS), objective pain score (OPS), and faces pain scale-revised (FPS-R).

2. Analgesic consumption: total morphine and/or fentanyl consumption.

3. Other operation indicators: side effects (pruritus and vomiting), intraoperative hemodynamic variables (HR: heart rate, MAP: mean arterial pressure), and extubation time in cardiovascular surgery patients.

4. Serum magnesium concentration.

The Jadad test (5 items) (12) was applied to assess methodological quality as high (score 5), moderate (score 4), or low (scores $1-3$ ).

\section{Data Synthesis and Analysis}

Because most outcomes were presented as continuous data (e.g., mean value or mean changes), either weighted mean differences (WMDs) or standardized mean difference (SMDs) were used for effect measures. WMDs were calculated for intraoperative hemodynamic variables, side effects, extubation time, and serum magnesium concentration outcomes because they were measured in different trials with the same scale. SMDs were calculated for pain outcomes (including pain score and analgesic consumption) because they were determined in different trials using different scales. Odds ratio (OR) was used to evaluate the incidence of side effects. WMD, SMD, or OR as well as their $95 \%$ confidence intervals
(Cls) were calculated for each subgroup. Data were analyzed using Review Manager analyses software (RevMan 5.0.25) according to the Cochrane Handbook for Systematic Reviews of Interventions (13). Based on these outputs, summary graphs were made with GraphPad Prism version 5.01 for Windows (Graph Pad Software, San Diego California USA, www.graphpad.com).

A sensitivity analysis was conducted to determine whether type of surgery (orthopedic, cardiovascular, gastrointestinal, or urogenital surgery) affected the meta-analysis conclusion.

\section{REsults}

\section{Baseline Characteristics}

The doses of magnesium, baseline demographic characteristics, exclusion criteria, surgery type, and Jadad score for every study are included in Table 1.

\section{Systemic Magnesium Delivery and Post- operative Pain}

Because the surgeries reported in the included RCTs were orthopedic, cardiovascular, gastrointestinal, or urogenital, we focused on the quality of analgesia on post-operative pain with regard to surgery type as well as at different time points, by assessing the mean differences and $95 \% \mathrm{Cl}$ between systemic magnesium and placebo groups.

\section{Orthopaedic surgery}

In this patient population, systemic magnesium induced a significantly increased post-operative analgesia indicated by both decrease in post-operative pain score (Fig. $2,-1.07,95 \% \mathrm{Cl},-1.28$ to $-0.87 ; P<0.01)$ and analgesic consumption (Fig. 3, morphine, $-3.00,95 \% \mathrm{Cl}$, -3.75 to $-2.25 ; P<0.01$; fentanyl, $-1.93,95 \% \mathrm{Cl},-2.64$ to $-1.22 ; P<0.01)$. The decrease in pain score was significant at $6(-1.51,95 \% \mathrm{Cl},-1.92$ to $-1.10 ; P<0.01$, from 2 RCTs) or 24 hours $(-0.92,95 \% \mathrm{Cl},-1.25$ to $-0.58 ; P<$ 0.01 , from 3 RCTs) after surgery. However, the decrease in pain score at 2, 12, or 48 hours after surgery was observed in only one single RCT, therefore, a concrete conclusion on these 2 time-points cannot be drawn.

Cardiovascular surgery: According to the statistical result in Fig. 2, systemic magnesium induced a significantly increased post-operative analgesia indicated by both decrease in post-operative pain score (Fig. 2, -1.45, $95 \% \mathrm{Cl},-1.59$ to $-1.32 ; P<0.01)$ and analgesic consumption (Fig. 3, morphine, $-0.09,95 \% \mathrm{Cl},-0.10$ to $-0.08 ; P<$ 0.01 ; fentanyl, $-0.09,95 \% \mathrm{Cl},-0.10$ to $-0.08 ; P<0.01$ ). 
The decrease in pain score was significant at $2(-0.84$, $95 \% \mathrm{Cl},-1.30$ to $-0.38 ; P<0.01$, from 2 RCTs), 6 (-1.64, $95 \% \mathrm{Cl},-1.84$ to $-1.44 ; P<0.01$, from 2 RCTs), and 12 hours $(-1.25,95 \% \mathrm{Cl},-1.52$ to $-0.98 ; P<0.01$, from 2 RCTs) after surgery. However, the decrease in pain score at 24 hours after surgery was observed in only one single RCT, therefore, a concrete conclusion on this time-point cannot be drawn.

\section{Gastrointestinal surgery}

According to the statistical result in Fig. 2, systemic magnesium did not increase post-operative analgesia indicated by the post-operative pain score alteration (Fig. 2, $-0.20,95 \% \mathrm{Cl},-0.48$ to $-0.08 ; P=0.07$ ). This zero effect was also confirmed in that systemic magnesium did increase the morphine (Fig. 3, $0.26,95 \% \mathrm{Cl},-0.11$ to $0.63 ; P<0.01)$ but not fentanyl $(-0.16,95 \% \mathrm{Cl},-0.19$ to
-0.13; $P=0.08)$ consumption. However, systemic magnesium did decrease the pain score at $2(-0.55,95 \% \mathrm{Cl}$, -0.86 to $-0.24 ; P<0.01$, from $3 \mathrm{RCTs})$ or $6(-0.13,95 \% \mathrm{Cl}$, -0.44 to $-0.17 ; P<0.01$, from 3 RCTs) hours, but not 24 (0.22, 95\% Cl, -0.38 to $0.83 ; P=0.35$, from $3 \mathrm{RCTs}), 48$ ( $-0.10,95 \% \mathrm{Cl},-0.48$ to $0.28 ; P=0.61$, from $2 \mathrm{RCTs})$ or 72 hours $(-0.07,95 \% \mathrm{Cl},-0.43$ to $0.29 ; P=0.69$, from 2 RCTs) after surgery.

\section{Urogenital surgery}

According to the statistical result in Fig. 2, systemic magnesium induced a significantly increased postoperative analgesia indicated by both decrease in postoperative pain score (Fig. 2, $-1.94,95 \% \mathrm{Cl},-2.64$ to -1.24 ; $P<0.01$ ) and analgesic consumption (Fig. 3, morphine, $-2.19,95 \% \mathrm{Cl},-2.63$ to $-1.74 ; P<0.01$; fentanyl, -5.19 , $95 \% \mathrm{Cl},-6.54$ to $-3.84 ; P<0.01)$. The decrease in pain

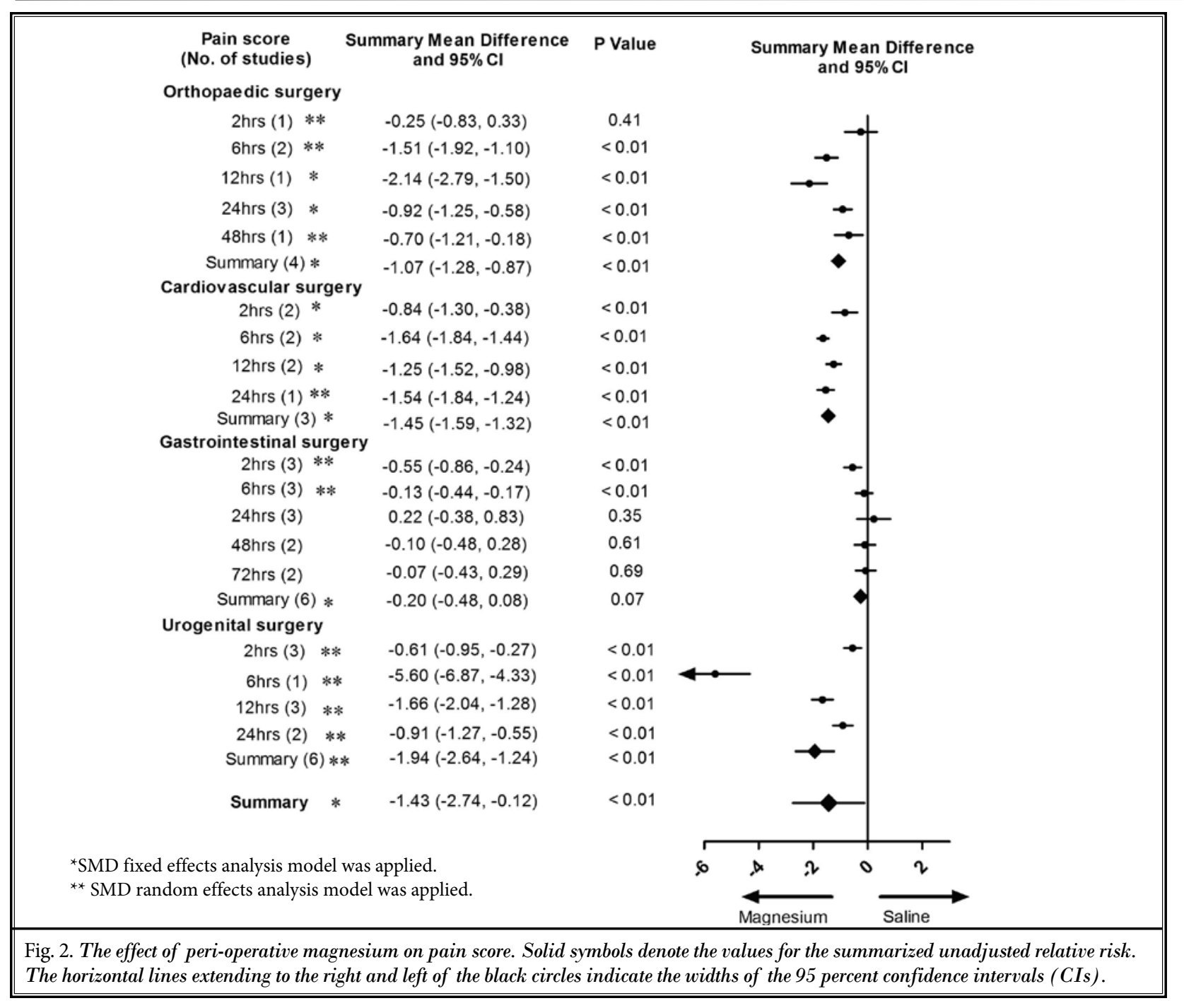




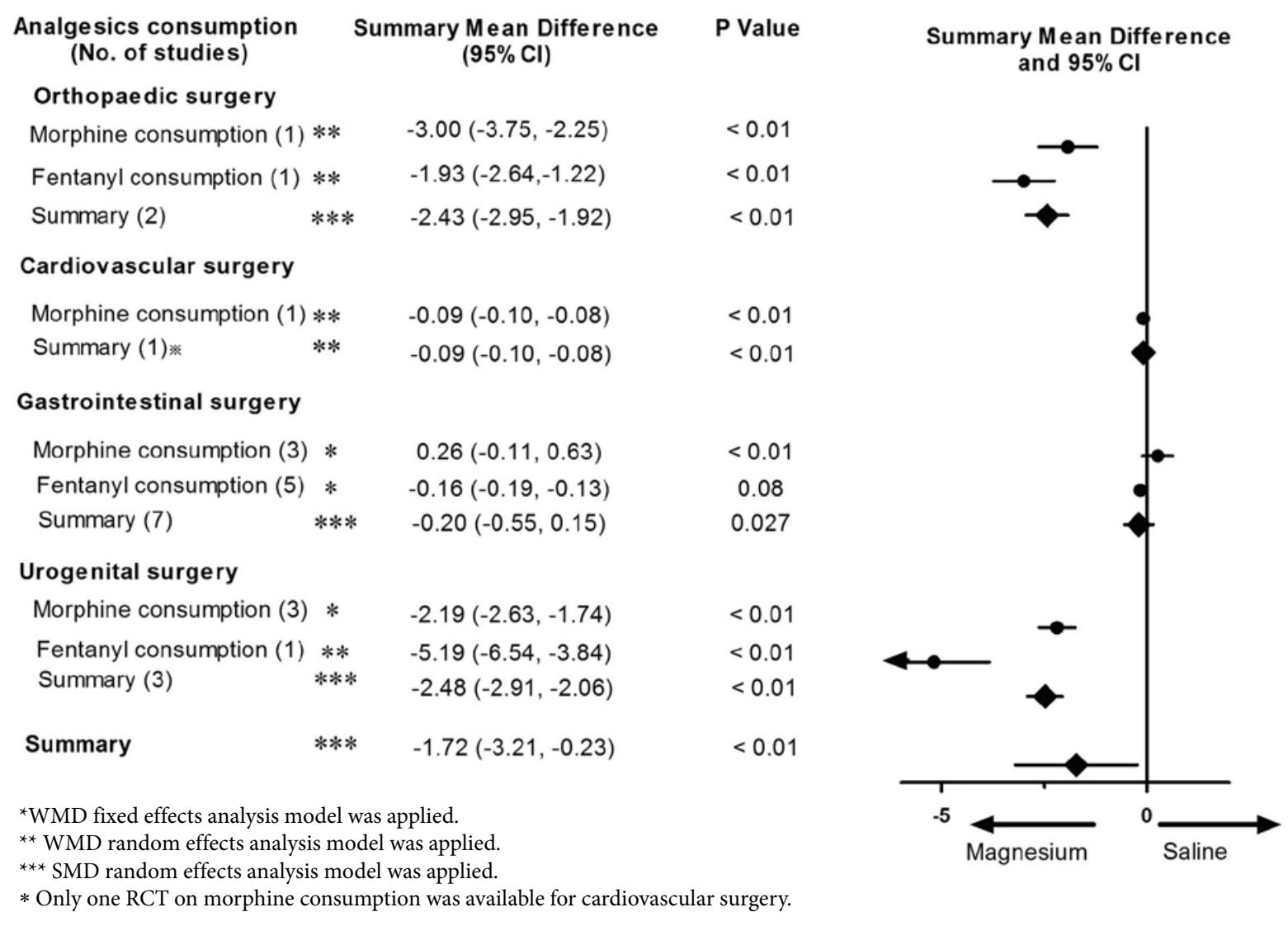

Fig. 3. The effect of peri-operative magnesium on post-operative analgesic consumption. Solid symbols denote the values for the summarized unadjusted relative risk. The horizontal lines extending to the right and left of the black circles indicate the widths of the 95 percent confidence intervals (CIs).

score was significant at $2(-0.61,95 \% \mathrm{Cl},-0.95$ to -0.27 ; $P<0.01$, from 3 RCTs), $12(-1.66,95 \% \mathrm{Cl}, 2.04$ to $-1.28 ; P$ $<0.01$, from $3 \mathrm{RCTs})$, and 24 hours $(-0.91,95 \% \mathrm{Cl},-1.27$ to -0.55 ; $P<0.01$, from 2 RCTs) after surgery. However, the decrease in pain score at 6 hours after surgery was observed in only one single RCT, therefore, a concrete conclusion at this time-point cannot be drawn.

\section{Systemic Magnesium Delivery and Extubation Time}

According to the results, there was strong evidence for the efficacy of magnesium in reducing extubation time among cardiovascular surgery patients. Sensitivity analysis revealed strong evidence for the reduction of extubation time for cardiovascular (Table 2, WMD,74.00, 95\% Cl, -84.38 to $-63.62 ; P<0.00001)$, but not urogenital (Table 2, WMD, $-2.26,95 \% \mathrm{Cl},-10.48$ to 5.96 ; $P=0.59$ ) or gastrointestinal (Table 2, WMD, 12.00, 95\%
$\mathrm{Cl},-43.52$ to $67.52 ; P=0.67)$ surgery patients.

\section{Systemic Magnesium Delivery and Intraoperative Hemodynamics}

There was strong evidence for reduction in both HR and MAP at one hour after surgery. Table 2 gives a comparison of the effect sizes for different type of patients and operations. Peri-operative magnesium-induced significant HR decrease was observed for urogenital (Table 2, WMD, $-11.60,95 \% \mathrm{Cl},-16.79$ to $-6.41, P<0.0001)$, but not gastrointestinal (Table 2, WMD, $-0.97,95 \% \mathrm{Cl},-2.08$ to $0.14, P=0.09$ ) or orthopedic (Table 2, WMD, -4.44 , $95 \% \mathrm{Cl},-11.23$ to $2.34, P=0.20$ ) surgery patients. Also peri-operative magnesium-induced significant MAP decrease was observed among urogenital (Table 2, WMD, $-9.10,95 \% \mathrm{Cl},-13.74$ to $-4.46, P=0.0001)$, gastrointestinal (Table 2, WMD, $-6.73,95 \% \mathrm{Cl},-9.90$ to $-3.57, P<$ 0.0001 ), and orthopedic (Table 2, WMD, $-8.16,95 \% \mathrm{Cl}$, 
Table 2. The effect of peri-operative magnesium on haemodynamics and adverse events.

\begin{tabular}{|c|c|c|c|c|c|}
\hline \multicolumn{2}{|c|}{ Outcomes } & No. of studies & $\begin{array}{l}\text { Patients receiving } \\
\text { magnesium No. }\end{array}$ & Effect size (95\% CI) & $\begin{array}{c}\text { Test of over effect } \\
P \text { value }\end{array}$ \\
\hline \multicolumn{6}{|c|}{ Orthopaedic surgery } \\
\hline \multicolumn{2}{|c|}{ HR } & 2 & 51 & $-4.44(-11.23,2.34)^{*}$ & 0.20 \\
\hline \multicolumn{2}{|l|}{ MAP } & 3 & 76 & $-8.16(-10.24,-6.07)^{\star}$ & $<0.00001$ \\
\hline \multicolumn{2}{|l|}{ ET* } & - & - & - & - \\
\hline \multicolumn{6}{|c|}{ Cardic surgery } \\
\hline \multicolumn{2}{|l|}{$\mathrm{HR} *$} & - & - & - & - \\
\hline \multicolumn{2}{|l|}{ MAP* } & - & - & - & - \\
\hline \multicolumn{2}{|l|}{ ET } & 1 & 109 & $-74.00(-84.38,-63.62)^{\star *}$ & $<0.00001$ \\
\hline \multicolumn{6}{|c|}{ Gastrointestinal surgery } \\
\hline \multicolumn{2}{|l|}{ HR } & 3 & 66 & $-0.97(-2.08,0.14)^{*}$ & 0.09 \\
\hline \multicolumn{2}{|l|}{ MAP } & 4 & 96 & $-6.73(-9.90,-3.57)^{*}$ & $<0.0001$ \\
\hline \multicolumn{2}{|l|}{ ET } & 1 & 21 & $12.00(-43.52,67.52)^{\star *}$ & 0.67 \\
\hline \multirow{2}{*}{$\begin{array}{l}\text { Side effects } \\
\dagger\end{array}$} & Vomit & 5 & 18 & $0.65(0.33,1.28)^{\star * *}$ & 0.21 \\
\hline & Pruritus & 3 & 64 & $0.95(0.18,4.93)^{\star * *}$ & 0.95 \\
\hline \multicolumn{6}{|c|}{ Gynaecological surgery } \\
\hline \multicolumn{2}{|l|}{ HR } & 1 & 20 & $-11.60(-16.79,-6.41)^{* *}$ & $<0.0001$ \\
\hline \multicolumn{2}{|l|}{ MAP } & 1 & 20 & $-9.10(-13.74,-4.46)^{* *}$ & 0.0001 \\
\hline \multicolumn{2}{|l|}{ ET } & 3 & 60 & $-2.26(-10.48,5.96)^{\star}$ & 0.59 \\
\hline
\end{tabular}

* WMD fixed effects analysis model was applied in these effect size analyses.

${ }^{* *}$ WMD random effects analysis model was applied in these effect size analyses.

$* * *$ OR fixed effects analysis model was applied in these effect size analyses.

* No data can be involved in these effect size analyses.

$\dagger$ Only side effects reported from digestive system operation related RCT were applied in these effect size analyses.

Abbreviations: HR, heart rate; MAP, mean arterial pressure; ET, extubated time

-10.24 to $-6.07, P<0.00001)$ surgery patients. The effect data in cardiovascular surgery for both HR and MAP were not reported in the selected studies.

\section{Systemic Magnesium Delivery and Serum Magnesium Concentration}

The current meta-analysis revealed that the magnesium concentration was significantly increased right after surgery (Table $3, \mathrm{WMD}, 0.52,95 \% \mathrm{Cl}, 0.47$ to 0.56 ; $P<0.00001)$. This difference existed for gastrointestinal (Table 3, WMD, $0.18,95 \% \mathrm{Cl}, 0.06$ to $0.30 ; P=0.003$ ), orthopedic (Table 3, WMD, $0.56,95 \% \mathrm{Cl}, 0.51$ to 0.61 ; $P<0.00001$ ), and cardiovascular (Table 3, WMD, 1.06, $95 \% \mathrm{Cl}, 0.76$ to $1.36 ; P<0.00001)$ surgery patients.

The significantly increased magnesium concentration was also observed at 24 hours after surgery (Table 3, WMD, $0.16,95 \% \mathrm{Cl}, 0.13$ to 0.19 ; $P<0.00001$ ), particularly for orthopedic surgery patients). Data for gastrointestinal and cardiovascular surgeries were not available.

\section{Systemic Magnesium Delivery and Side Effects}

Six studies provided the number of side effects with magnesium compared to placebo in a total of 269 patients receiving gastrointestinal surgery. Eighteen of $134(13.4 \%)$ patients assigned to magnesium reported vomiting compared to 26 of 135 (19.2\%) allocated to placebo. Three of $64(4.7 \%)$ patients assigned to magnesium reported pruritus compared to 3 of $65(4.6 \%)$ allocated to placebo. The evidence (Table 2) indicated that magnesium did not reduce the incidence of vomiting (Table 2, OR, $0.65 ; 95 \% \mathrm{Cl}, 0.33$ to $1.28, P=0.21$ ) or pruritus (Table 2, OR, $0.95 ; 95 \% \mathrm{Cl}, 0.18$ to $4.93, P=$ $0.95)$, with no heterogeneity detected between studies $(12=0 \%, P=0.91 ; 12=0 \%, P=0.40)$.

\section{Validity Analysis}

Seventeen studies had a Jadad score of $5 ; 6$ studies, a score of 4 ; 3 studies, a score of 3 ; and one study, a score of $2(14-40)$. Considering that some of the in- 
Effects of Systemic Magnesium on Post-operative Analgesia

Table 3. The effect of peri-operative magnesium and serum magnesium concentration.

\begin{tabular}{|c|c|c|c|c|c|c|}
\hline & \multicolumn{2}{|c|}{ Before operation } & \multicolumn{2}{|c|}{ O minutes after operation } & \multicolumn{2}{|c|}{24 hours after operation } \\
\hline & $\begin{array}{l}\text { Effect size } \\
(95 \% \mathrm{CI})\end{array}$ & $\begin{array}{c}\text { Test of over } \\
\text { effect } P \text { value }\end{array}$ & $\begin{array}{l}\text { Effect size } \\
(95 \% \mathrm{CI})\end{array}$ & $\begin{array}{c}\text { Test of over } \\
\text { effect } P \text { value }\end{array}$ & $\begin{array}{l}\text { Effect size } \\
(95 \% \mathrm{CI})\end{array}$ & $\begin{array}{c}\text { Test of over } \\
\text { effect } P \text { value }\end{array}$ \\
\hline Orthopaedic surgery & $\begin{array}{c}-0.01 \\
(-0.03,0.01)^{*}\end{array}$ & 0.39 & $\begin{array}{c}0.56 \\
(0.51,0.61)^{*}\end{array}$ & $<0.00001$ & $0.16(0.13,0.19)^{\star *}$ & $<0.00001$ \\
\hline Cardiovascular surgery & $\begin{array}{c}0 \\
(-0.11,0.11) \dagger^{* *} \\
\end{array}$ & 1 & $\begin{array}{c}1.06 \\
(0.76,1.36)^{\star *}\end{array}$ & $<0.00001$ & - & - \\
\hline Gastrointestinal surgery & $\begin{array}{c}-0.10 \\
(-0.19,-0.01)^{*}\end{array}$ & 0.03 & $\begin{array}{c}0.18 \\
(0.06,0.30)^{*}\end{array}$ & 0.003 & - & - \\
\hline Gynaecological surgery* & - & - & - & - & - & - \\
\hline Total & $\begin{array}{c}-0.02 \\
(-0.04,0.01)^{\star}\end{array}$ & 0.17 & $\begin{array}{c}0.52 \\
(0.47,0.56)^{\star}\end{array}$ & $<0.00001$ & $0.16(0.13,0.19)^{*}$ & $<0.00001$ \\
\hline
\end{tabular}

${ }^{\star}$ WMD fixed effects analysis model was applied in these effect size analyses.

** WMD random effects analysis model was applied in these effect size analyses.

$*$ Data from Urogenital surgery were not available.

cluded articles in the previous meta-analysis have low Jadad scores, we made another evaluation of the RCTs with Jadad scores over 4, which resulted in the inclusion of 23 RCTs. Most of the results are similar to those before study deletion. Post-operative pain score for gastrointestinal surgery still showed no evident reduction but the statistical results for the total test and at 2 hours after surgery have been significantly changed (pain score, summary, SMD, $-0.08,95 \% \mathrm{Cl},-0.28$ to 0.11 ; $P=0.40 ; 2 \mathrm{~h}, \mathrm{SMD},-0.37,95 \% \mathrm{Cl},-1.05$ to $0.31 ; P=0.28)$. For gastrointestinal surgery, post-operative pain score is significantly decreased at only 2 and 24 hours (pain score, 2 hours, SMD, $-1.97,95 \% \mathrm{Cl},-2.65$ to $-1.28 ; P<$ $0.00001 ; 24$ hours SMD, $-0.97,95 \% \mathrm{Cl},-1.74$ to $-0.21 ; P=$ 0.01 ) after surgery. In conclusion, the exclusion of those studies did not change the overall conclusions.

\section{Discussion}

The primary aim of this meta-analysis was to determine the analgesic efficacy and safety of peri-operative systemic magnesium for post-operative pain. Strong evidence was demonstrated for the efficacy of magnesium in reducing post-operative pain and improving surgery quality (except in the case of gastrointestinal surgery). The beneficial effects of magnesium were observed in both orthopedic and cardiovascular surgeries at the first 24 hours after operation. The analgesic effect lasted until 48 hours after orthopedic surgery. The analgesic effect of magnesium declined after the first 24 hours in urogenital and cardiovascular surgeries, suggesting the necessity of combining other medications to extend analgesic duration.
There might be significant age- or gender-related differences in magnesium-mediated analgesia. In the current meta-analysis, 2 RCTs focusing on the pediatric population demonstrated positive results $(31,39)$. However, there was no significant difference between magnesium and placebo groups in different ages of adults. The results of the present investigation revealed that children appear to be more sensitive to magnesium than adults. Further, only 3 RCTs were designed for women and no matched male populations were included; therefore, conclusions of gender differences remain unclear. Therefore, future high-quality RCTs are needed to clarify the roles of age and gender on magnesium-mediated post-operative analgesia.

As for intraoperative hemodynamics, magnesium reduces HR and MAP, which can potentially lead to intra- and post-operative beneficial effects (2). Therefore, the use of magnesium in surgical operations can potentially avoid or minimize certain adverse cardiovascular and/or cerebrovascular events.

For serum magnesium concentration, a positive correlation between blood levels and post-operative analgesia was identified. However, the concentration of serum magnesium should be carefully monitored in order to prevent hypermagnesaemia, which can cause many adverse effects, including sedation, diarrhea, potentiation of neuromuscular blockade, cardiac arrhythmia, respiratory depression, and other adverse effects on the cardiovascular and renal systems (40). Notably, because of the potential adverse effects of hypermagnesaemia, a certain population may not be suitable to receive systemic magnesium. Unfortunately, studies on 
this issue are lacking and further high quality RCTs on the contraindications of different magnesium delivery plans are needed.

This review has a number of limitations. First, there are differences with regard to the methods by which magnesium was administered in the studies. Because the number of RCTs which epidural and intra-articular pathways were utilized is limited, only intravenous magnesium was included in this investigation. However, we did notice the potential clinical role of other administration methods based on related literature (41). As a result, future research on this issue is warranted. Second, when to deliver and when to end magnesium varied and there is no consensus for magnesium dosages. We could not, therefore, stratify the effect of dose and time, though we are fully aware of their importance. And whether different dosages of magnesium may result in distinct side effects is difficult to analyze based on the current evidence. Thus, it is still too early for us to give comments on magnesium delivery plans, and more high-quality RCTs designed to assess the efficacy and safety of different magnesium delivery plans are needed, which is critically important for us to transfer this intervention into clinical practice. Third, there were limitations with some methods used in this article, such as using 12 for assessing the amount of heterogeneity in random-effects meta-analysis and fail-safe numbers for excluding a publication bias. Fourth, the conclusions obtained from the current meta-analysis are preliminary given that there are 7 ongoing RCTs and 11 completed RCTs without published data (Supplementary Tables 1 and 2).

\section{Conclusion}

In summary, the present investigation demonstrated that systemic magnesium during general anesthesia significantly decreases post-operative pain scores without increasing adverse events. Given that there are 18 ongoing RCTs without published data, it is still premature to draw conclusions on the long-term analgesic effects of magnesium as well as potential gender- or age-related differences.

\section{Competing Interest Statement}

All authors have completed the Unified Competing Interest form and declare: no financial relationships with any organizations that might have an interest in the submitted work and no other relationships or activities that could appear to have influenced the submitted work.

\section{Acknowledgments}

This work was partly supported by National Natural Science Foundation of China (Nos. 81222015, 31070976, 81271230), Program for New Century Excellent Talents in University of China, Innovation International Science \& Technology Cooperation Program of China (2011DFA32560), Program for Shaanxi Province Key Research Team of Science and Technology Innovation (2012KCT-14), and intramural grant of the Fourth Military Medical University. The funders had no role in the designing, conducting, and submission of this work. 


\section{Effects of Systemic Magnesium on Post-operative Analgesia}

Supplementary Table 1. Ongoing RCTs on the topic of "magnesium and postoperative analgesia."

\begin{tabular}{|c|c|c|c|c|c|c|}
\hline Trial No. & $\begin{array}{l}\text { Registered } \\
\text { time }\end{array}$ & Title & Outcomes & Interventions & Country & Status \\
\hline NCT01460563 & $\begin{array}{l}\text { October } \\
2011\end{array}$ & $\begin{array}{l}\text { Valproic Acid, Magnesium Sulphate, } \\
\text { Rocuronium Requirement, } \\
\text { Postoperative Analgesia }\end{array}$ & $\begin{array}{l}\text { total amount of anesthetics } \\
\text { pain } \\
\text { analgesics use }\end{array}$ & $\begin{array}{l}\text { Magnesium Sulfate } \\
0.9 \% \text { saline }\end{array}$ & South Korea & Recruiting \\
\hline NCT01795495 & $\begin{array}{l}\text { September } \\
2013\end{array}$ & $\begin{array}{l}\text { Methadone vs Magnesium in Spinal } \\
\text { Fusion }\end{array}$ & $\begin{array}{l}\text { Intra- and Post-operative } \\
\text { Pain Relief }\end{array}$ & $\begin{array}{l}\text { Methadone } \\
\text { hydrochloride } \\
\text { Magnesium Sulfate } \\
\text { Remifentanil }\end{array}$ & USA & Recruiting \\
\hline NCT01542697 & June 2011 & $\begin{array}{l}\text { Effect of Intraperitoneal Nebulisation } \\
\text { of Magnesium Sulphate for } \\
\text { Analgesia Following Laparoscopic } \\
\text { Cholecystectomy }\end{array}$ & $\begin{array}{l}\text { number of analgesic request } \\
\text { VAS score }\end{array}$ & $\begin{array}{l}\text { i.p. magnesium } \\
\text { sulphate }\end{array}$ & Nepal & Recruiting \\
\hline NCT02018276 & $\begin{array}{l}\text { December } \\
2013\end{array}$ & $\begin{array}{l}\text { Effect of Perioperative Intravenous } \\
\text { Lidocaine Infusion and Magnesium } \\
\text { Infusion on the Functional Recovery } \\
\text { After General Anesthesia in the } \\
\text { Patients Undergoing Thyroid Surgery }\end{array}$ & QoR 40 & $\begin{array}{l}\text { Lidocaine } \\
\text { Magnesium }\end{array}$ & South Korea & Recruiting \\
\hline NCT01627353 & $\begin{array}{l}\text { January } \\
2012\end{array}$ & $\begin{array}{l}\text { Post Hysterectomy Pain Prevention: } \\
\text { Pre-op Wound Infiltration With } \\
\text { Anesthetic Protocol Versus Standard } \\
\text { of Care }\end{array}$ & $\begin{array}{l}\text { Post Operative Morphine } \\
\text { VAS score }\end{array}$ & $\begin{array}{l}\text { Standard of care } \\
\text { Pre-emptive wound } \\
\text { infiltration }\end{array}$ & Canada & Recruiting \\
\hline NCT02087202 & March 2014 & $\begin{array}{l}\text { Hyperalgesia and NMDA Receptor } \\
\text { Antagonist }\end{array}$ & pain & $\begin{array}{l}\text { Magnesium Sulfate } \\
\text { ketamine }\end{array}$ & South Korea & $\begin{array}{l}\text { Not yet } \\
\text { recruiting }\end{array}$ \\
\hline NCT01923831 & $\begin{array}{l}\text { August } \\
2013\end{array}$ & $\begin{array}{l}\text { Comparison of the Effect } \\
\text { of Magnesium Sulfate and } \\
\text { Dexamethasone on Postoperative Sore } \\
\text { Throat After Spinal Surgery in Prone } \\
\text { Position With Tracheal Intubation: } \\
\text { a Double-blind, Randomized, } \\
\text { Noninferiority Clinical Trial }\end{array}$ & NA & $\begin{array}{l}\text { Magnesium Sulfate } \\
\text { dexamethasone }\end{array}$ & South Korea & $\begin{array}{l}\text { Not yet } \\
\text { recruiting }\end{array}$ \\
\hline
\end{tabular}


Pain Physician: September/October 2015; 18:405-417

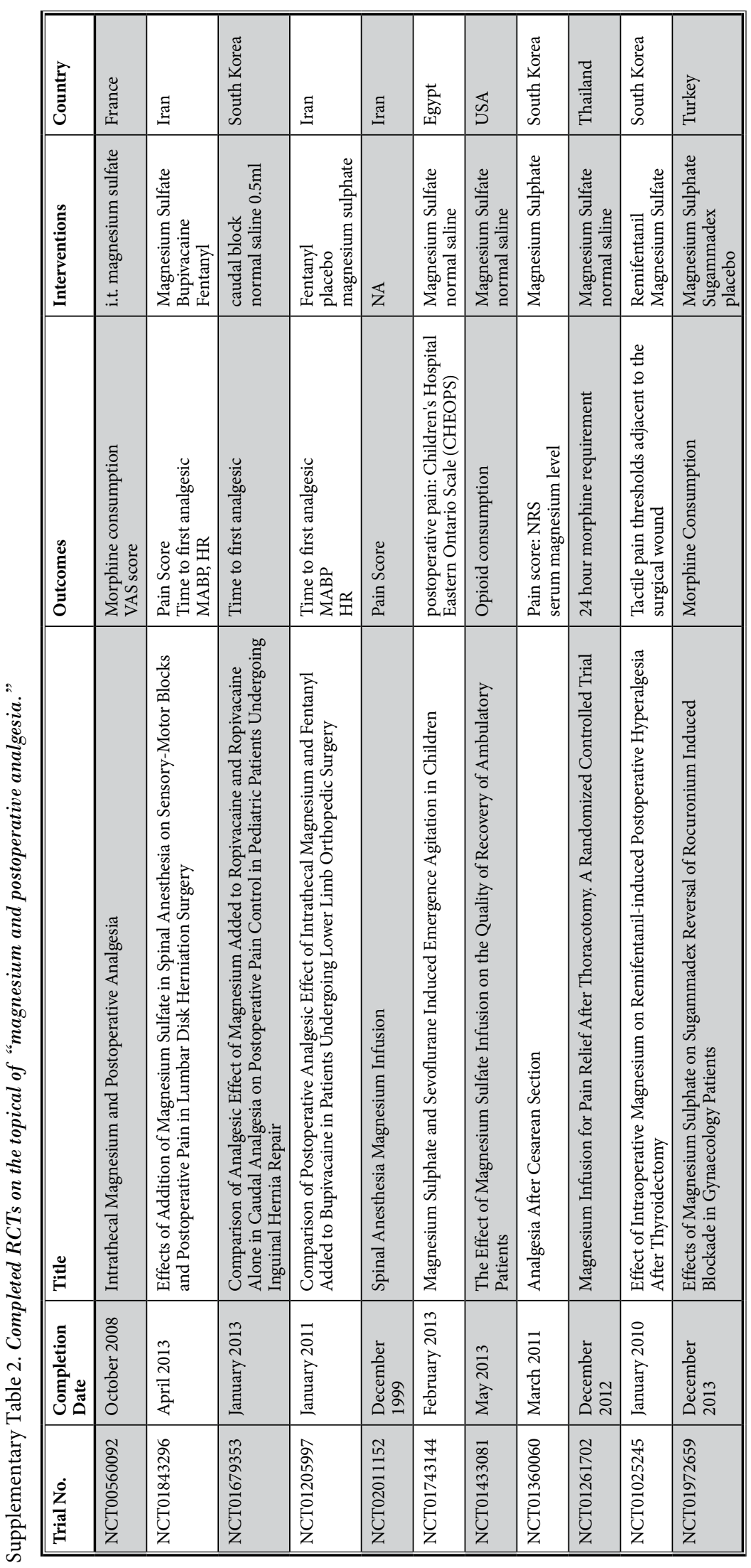




\section{References}

1. Mebazaa MS, Ouerghi S, Frikha N, Moncer K, Mestiri T, James MF, Ben Ammar MS. Is magnesium sulfate by the intrathecal route efficient and safe? Annales Francaises d'anesthesie et de Reanimation 2011; 30:47-50.

2. Tramer MR, Schneider J, Marti RA, Rifat $K$. Role of magnesium sulfate in postoperative analgesia. Anesthesiology 1996; 84:340-347.

3. Jaoua H, Zghidi SM, Wissem L, Laassili S, Ammar N, Ali J, Darmoul S, Askri A, Khelifi S, Ben Maamer A, Cherif A, Ben Fadhel K. [Effectiveness of intravenous magnesium on postoperative pain after abdominal surgery versus placebo: Double blind randomized controlled trial]. La Tunisie Medicale 2010; 88:317-323.

4. Tramer MR, Glynn CJ. An evaluation of a single dose of magnesium to supplement analgesia after ambulatory surgery: Randomized controlled trial. Anesth Analg 2007; 104:1374-1379.

5. Zarauza R, Saez-Fernandez AN, Iribarren MJ, Carrascosa F, Adame M, Fidalgo I, Monedero P. A comparative study with oral nifedipine, intravenous nimodipine, and magnesium sulfate in postoperative analgesia. Anesth Analg 2000; 91:938-943.

6. McCartney CJ, Sinha A, Katz J. A qualitative systematic review of the role of $\mathrm{N}$-methyl-D-aspartate receptor antagonists in preventive analgesia. Anesth Analg 2004; 98:1385-1400.

7. Lysakowski C, Dumont L, Czarnetzki C, Tramer MR. Magnesium as an adjuvant to postoperative analgesia: A systematic review of randomized trials. Anesth Analg 2007; 104:1532-1539.

8. De Oliveira GS, Jr., Castro-Alves LJ, Khan $\mathrm{JH}, \mathrm{McC}$ arthy RJ. Perioperative systemic magnesium to minimize postoperative pain: A meta-analysis of randomized controlled trials. Anesthesiology 2013; 119:178-19o.

9. Albrecht E, Kirkham KR, Liu SS, Brull R. Peri-operative intravenous administration of magnesium sulphate and postoperative pain: A meta-analysis. Anaesthesia 2013; 68:79-90.

10. Moher D, Cook DJ, Eastwood S, Olkin I, Rennie D, Stroup DF. Improving the quality of reports of meta-analyses of randomised controlled trials: the QUOROM statement. Quality of Reporting of Meta-analyses. Lancet 1999; 354:1896-1900.

11. Bero L, Rennie D. The Cochrane Col- laboration. Preparing, maintaining, and disseminating systematic reviews of the effects of health care. JAMA 1995; 274:1935-1938.

12. Jadad AR, Moore RA, Carroll D, Jenkinson C, Reynolds DJ, Gavaghan DJ, McQuay HJ. Assessing the quality of reports of randomized clinical trials: Is blinding necessary? Controlled Clinical Trials 1996; 17:1-12.

13. GS HJ. Cochrane Handbook for Systematic Reviews of Interventions Version 502 [updated September 2009]. The Cochrane Collaboration, 2009.

14. Kunduracilar Z, Ayoglu FN, Erdemli O. The analgesic effect of magnesium sulfate and ketamine in patients undergoing laparoscopic cholecystectomy. The Pain Clinic 2007; 17:45-53.

15. Bhatia A, Kashyap L, Pawar DK, Trikha A. Effect of intraoperative magnesium infusion on perioperative analgesia in open cholecystectomy. Journal of Clinical Anesthesia 2004; 16:262-265.

16. Dabbagh A, Elyasi H, Razavi SS, Fathi M, Rajaei S. Intravenous magnesium sulfate for post-operative pain in patients undergoing lower limb orthopedic surgery. Acta Anaesthesiologica Scandinavica 2009; 53:1088-1091.

17. Ferasatkish R, Dabbagh A, Alavi M, Mollasadeghi G, Hydarpur E, Moghadam AA, Faritus ZS, Totonchi MZ. Effect of magnesium sulfate on extubation time and acute pain in coronary artery bypass surgery. Acta Anaesthesiologica Scandinavica 2008; 52:1348-1352.

18. Oguzhan N, Gunday I, Turan A. Effect of magnesium sulfate infusion on sevoflurane consumption, hemodynamics, and perioperative opioid consumption in lumbar disc surgery. J Opioid Manage 2008; 4:105-110.

19. Seyhan TO, Tugrul M, Sungur MO, Kayacan S, Telci L, Pembeci K, Akpir K. Effects of three different dose regimens of magnesium on propofol requirements, haemodynamic variables and postoperative pain relief in gynaecological surgery. British Journal of Anaesthesia 2006; 96:247-252.

20. Tauzin-Fin P, Sesay M, Delort-Laval S, Krol-Houdek MC, Maurette P. Intravenous magnesium sulphate decreases postoperative tramadol requirement after radical prostatectomy. European Journal of Anaesthesiology 2006; 23:1055-1059.

21. Hwang JY, Na HS, Jeon YT, Ro YJ, Kim CS, Do SH. I.V. infusion of magnesium sulphate during spinal anaesthesia improves postoperative analgesia. British Journal of Anaesthesia 2010; 104:89-93.

22. Schulz-Stubner S, Wettmann G, ReyleHahn SM, Rossaint R. Magnesium as part of balanced general anaesthesia with propofol, remifentanil and mivacurium: A double-blind, randomized prospective study in 50 patients. European Journal of Anaesthesiology 2001; 18:723-729.

23. Koinig $\mathrm{H}$, Wallner $\mathrm{T}$, Marhofer $\mathrm{P}, \mathrm{An}$ del $\mathrm{H}$, Horauf K, Mayer N. Magnesium sulfate reduces intra- and postoperative analgesic requirements. Anesthesia and Analgesia 1998; 87:206-210.

24. Mentes O, Harlak A, Yigit T, Balkan A, Balkan M, Cosar A, Savaser A, Kozak O, Tufan T. Effect of intraoperative magnesium sulphate infusion on pain relief after laparoscopic cholecystectomy. Acta Anaesthesiologica Scandinavica 2008; 52:1353-1359.

25. Ko SH, Lim HR, Kim DC, Han YJ, Choe H, Song HS. Magnesium sulfate does not reduce postoperative analgesic requirements. Anesthesiology 2001; 95:640-646.

26. Saadawy IM, Kaki AM, Abd El Latif AA, Abd-Elmaksoud AM, Tolba OM. Lidocaine vs. magnesium: Effect on analgesia after a laparoscopic cholecystectomy. Acta Anaesthesiologica Scandinavica 2010; 54:549-556.

27. Ryu JH, Kang MH, Park KS, Do SH. Effects of magnesium sulphate on intraoperative anaesthetic requirements and postoperative analgesia in gynaecology patients receiving total intravenous anaesthesia. British Journal of Anaesthesia 2008; 100:397-403.

28. Kiran S, Gupta R, Verma D. Evaluation of a single-dose of intravenous magnesium sulphate for prevention of postoperative pain after inguinal surgery. Indian Journal of Anaesthesia 2011; 55:31-35.

29. Kara H, Sahin N, Ulusan V, Aydogdu T. Magnesium infusion reduces perioperative pain. European Journal of Anaesthesiology 2002; 19:52-56.

30. Kaya S, Kararmaz A, Gedik R, Turhanoglu S. Magnesium sulfate reduces postoperative morphine requirement after remifentanil-based anesthesia. Medical Science Monitor 2009; 15: $\mathrm{Pl}_{5}-\mathrm{Pl}$.

31. $\mathrm{Na} \mathrm{HS}$, Lee JH, Hwang JY, Ryu JH, Han $\mathrm{SH}$, Jeon YT, Do SH. Effects of magnesium sulphate on intraoperative neuromuscular blocking agent requirements 
and postoperative analgesia in children with cerebral palsy. British Journal of Anaesthesia 2010; 104:344-350.

32. Labrada A. Analgesia multimodal preventiva: Estudio comparativo. RevsocEspDolor 2004; 11:122-128.

33. Steinlechner B, Dworschak $M$, Birkenberg B, Grubhofer G, Weigl M, Schiferer A, Lang T, Rajek A.Magnesium moderately decreases remifentanil dosage required for pain management after cardiac surgery. British Journal of Anaesthesia 2006; 96:444-449.

34. AQ HU. Evaluation of perioperative magnesium sulphate infusion on postoperative pain and analgesic requirements in patients undergoing upper abdominal surgery? J Anesth Clin Pharmacology 2007; 23:255-258.

35. Tan TY, Hu XG, Xiao YF. The effect of magnesium sulphate on postoperative pain after laparosopic cholecystectomy. Journal of Clinical Research 2006; 23:1922-1924.

36. Tramer MR Glynn C. An evaluation of a single dose of magnesium to supplement analgesia after ambulatory surgery: Randomized controlled trial. Anesthesia and Analgesia 2007; 104:1374-1379.

37. Jaoua H, Zghidi SM, Wissem L, Laassili S, Ammar N, Ali J, Darmoul S, Askri A, Khelifi S, Ben Maamer A, Cherif A, Ben Fadhel K. [Effectiveness of intravenous magnesium on postoperative pain after abdominal surgery versus placebo: Double blind randomized controlled trial]. La Tunisie Medicale 2010; 88:317-323.

38. Mavrommati P D, Gabopoulou Z T, Papadimos C N, Petsikopoulos MG, Vrettou VA, Konstantinidou MG, Velmachou
KG. The perioperative infusion of low dose of magnesium sulfate reduces analgesic requirement in patients undergoing abdominal hernioplasty. Acute Pain 2004; 5:81-87.

39. O'Flaherty JE, Lin CX. Does ketamine or magnesium affect posttonsillectomy pain in children? Paediatric Anaesthesia 2003; 13:413-421.

40. Vejlsted H, Eliasen P. Postoperative serum level and urinary excretion of magnesium following heart surgery. Scandinavian Journal of Thoracic and Cardiovascular Surgery 1978; 12:91-94.

41. Farouk S. Pre-incisional epidural magnesium provides pre-emptive and preventive analgesia in patients undergoing abdominal hysterectomy. British Journal of Anaesthesia 2008; 101:694-699. 